Research Article

\title{
Enhancing Students' Blended Learning Experience through Embedding Metaliteracy
}

\author{
Jieming Ma $\mathbb{D},{ }^{1}$ Chili Li, $^{2}$ and Hai-Ning Liang $\mathbb{D}^{1}$ \\ ${ }^{1}$ Department of Computer Science and Software Engineering, Xi'an Jiaotong-Liverpool University, Suzhou, Jiangsu Province, \\ 215123, China \\ ${ }^{2}$ School of Foreign Languages, Hubei University of Technology, Wuhan, Hubei Province, 430068, China \\ Correspondence should be addressed to Jieming Ma; jieming84@gmail.com
}

Received 29 January 2019; Revised 12 March 2019; Accepted 31 March 2019; Published 28 April 2019

Academic Editor: Yi-Shun Wang

Copyright (C) 2019 Jieming Ma et al. This is an open access article distributed under the Creative Commons Attribution License, which permits unrestricted use, distribution, and reproduction in any medium, provided the original work is properly cited.

As the push for a diversified use of information technologies in higher education teaching continues, a growing number of colleges and universities have come to adopt blended learning which combines traditional face-to-face lectures with online instruction to create flexible approaches of delivering content that are consistent with the requirements of new digital economy. At the same time, university students are required to have continuous growth in literacy skills. Metaliteracy is a comprehensive model for information literacy that can enhance blended learning experience. Embedding metaliteracy learning in a blended course is considered as a feasible approach to empower students in blended learning. Combining an analysis of data gathered through a survey administered at Xi'an Jiaotong-Liverpool University, a Sino-UK institution located in China, this paper reports the results of an investigation into the pedagogical issues including the metaliteracy learning experience of using an interactive communication environment and the benefits and challenges of integrating practices of metaliteracy with blended learning.

\section{Introduction}

With the advent of the digital age, online learning is not new to higher education and has been extensively researched, particularly at universities that specialize in teaching students online [1]. More and more courses are offered through blended learning, which uses a good number of online resources and activities to provide active, individualized, student-centered learning experiences for students [2]. It is challenging to find a widely accepted definition of blended learning and even more difficult to find a core set of literature on blended learning mythologies or framework [3]. In a crude manner, blended learning is considered as the combination of education and educational technology [4]. It takes advantage of differentiated instruction to best serve individual students' needs based on students' learning styles, knowledge level, interests, abilities, and skills [5].

Recent research shows that the students who have not experienced online learning may struggle with acquiring the crucial skills to function well in a blended learning environment [6]. The effective use of information by students has become a must in blended learning [7]. Information literacy skills, first appeared in Paul G. Zurkowski's report, are essential and basic abilities to know what information is required, where to find it, and how to evaluate, use, and communicate it in an ethical way [8]. When students obtain adequate information literacy skills, they can think critically, interpret information, and make informed judgements. Their ability to work independently is therefore improved [9].

People today live in a world with unparalleled access to a vast array of online information and experiences. In addition, it has become possible for anyone to use mobile technologies (e.g., smartphones, cameras, and voice recorders) which enable learning beyond the classroom walls. Related research has shown that academic study requires continuous literacy growth. New innovative information technologies, such as social media environments and online communities, challenge traditional definitions of information literacy [10]. Metaliteracy, developed by Mackey and Jacobson [10], not only expands the scope of traditional information skills (determine, access, locate, understand, produce, and use information) but also seeks a unifying 
model that builds on the core information literacy competencies while addressing the revolutionary changes in how learners communicate, create, and distribute information and participatory environments. Metaliterate individuals know their literacy strengths, while recognizing areas for improvement, and then adapt their own learning. As such, it requires a higher level of understanding of one's own knowledge and cognitive abilities-metacognition. If cognition involves perceiving, understanding, remembering, and so forth, then metacognition involves thinking about how one perceives, understands, remembers, etc. [11]. Therefore, it also calls upon metaliterate individuals to be active and self-reflective while critically engaging in the collaborative spaces of today's social media age.

Bruce [12] argued that information literacy education brings real life experiences of information use into the classroom, helping students develop other forms of academic literacy such as critical awareness and foster independent learning. In this sense, applying metacognition to metaliteracy practices can help students better understand metaliteracy and what it means for learning, enhancing learners' blended learning experiences. This paper reflects upon the potential for integrating the metaliteracy model in blended courses with an interactive communication environment (ICE) at Xi'an Jiaotong-Liverpool University (XJTLU), a Sino-UK institution located in China. The ICE was developed based on several concepts drawn from the metaliteracy model and provides many useful activities and features for blended learning. Since 2006, almost all courses offered at XJTLU have used ICE as the primary delivery platform for online content. Fostering information literacy appropriately in a blended context is as crucial a question as it has been in a face-to-face context [10]. It is hypothesized that metaliteracy could be considered as a feasible approach to empower students in blended learning. A survey was made to investigate the pedagogical issues including the metaliteracy learning experience of using an interactive communication environment and the benefits and challenges of integrating practices of metaliteracy with blended learning.

This paper is organized as follows. The framework of metaliteracy mode is described in Section 2. The theories that supported the metaliteracy learning will be discussed along with their implications to teaching and learning with ICE in Section 3. Section 4 surveys students' metaliteracy learning and satisfaction in blended courses. Conclusions are described in the last section.

\section{Metaliteracy}

With the enormous development in the field of information technology, there has been a need for an expanded metaliteracy framework. Elmborg [13] suggested that learners develop critical consciousness and take control of their lives and their own learning to become active agents. Ingraham et al. [14] proposed that information literacy itself may be seen as a metaliteracy that in the networked environment embraces a range of other literacies when the focus is on interaction with information irrespective of the medium.
Although this redefinition of information literacy is not comprehensive, the assertion indicates the interrelationships among information literacies.

The term metaliteracy expands the scope of information literacy as more than a set of discrete skills, challenging us to rethink information literacy as active knowledge production and distribution in collaborative online communities [10]. The use of metaliteracy suggests a means of thinking about one's own literacy, which emphasizes critical thinking and reflection required to engage in these spaces as producers, collaborators, and distributors. In [15], metaliteracy is considered as the ability to critically self-assess different competencies and to recognize one's need for integrated literacies in today's information environment. Mackey and Jacobson [10] conclude that "metaliteracy promotes critical thinking and collaboration in a digital age, providing a comprehensive framework to effectively participate in social media and online communities. It is a unified construct that supports the acquisition, production, and sharing of knowledge in collaborative online communities. Metaliteracy challenges traditional skills-based approaches to information literacy by recognizing related literacy types and incorporating emerging technologies." Therefore, metaliteracy provides a new conceptual framework for information literacy that diminishes theoretical differences, builds practical connections, and reinforces central lifelong learning goals among different literacy types [16].

The metaliteracy model provides a comprehensive overview of information literacy to advance critical thinking and reflection in social media, mobile technology, online communities, and open educational resources. Figure 1 shows the metaliteracy model in which all the elements are presented by a series of permeable spheres. At the center, information literacy is represented as metaliteracy. It is surrounded by a layer of metacognition, which is a part of a learning strategy based on a reflective understanding of how and why learners study, how well the students master the knowledge, and how they continue to learn. In the model, metacognition expands the scope of original information literacy to include determining, accessing, understanding, and evaluating information. We can identify that metaliteracy can be mediated by social media, mobile technology, online communities, and open educational resources (OERs). As demonstrated in [15], the modern learning environments are social, multimodal, interactive, and open, which require an integration of visual, textual, aural, media, digital, and collaborative competencies. Besides skills development, the metaliteracy model also places a stronger emphasis on producing and sharing information in participatory environments. The outer domain adds a set of competencies which are considered as part of our contemporary society, such as the abilities to collaborate, incorporate, participate, use, produce, and share information.

\section{Interactive Communication Environment (ICE)}

The interactive communication environment (ICE) is an online platform designed to support and enhance blended learning, distance education, flipped classroom, and other 


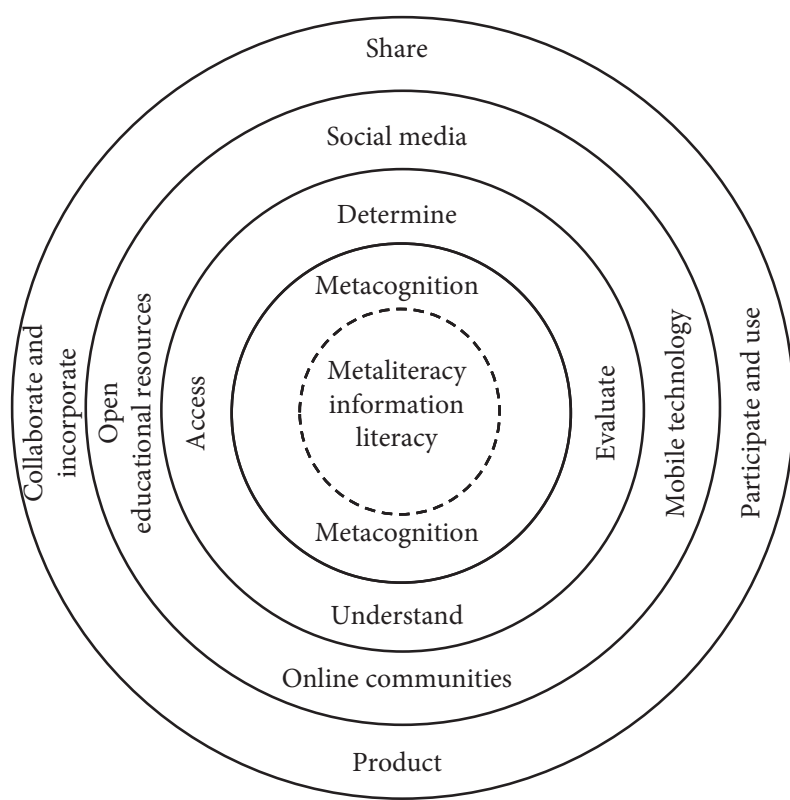

FIgURE 1: Metaliteracy model (adapted from [15]).

e-learning activities at Xi'an Jiaotong-Liverpool University (XJTLU). ICE was built based on several concepts drawn from the metaliteracy model and contains a good number of features. As shown in Figure 2, these features can be grouped into three units: resources, activities, and communications. Students can access ICE anytime, anywhere, and stay up-todate with the modules, view important resources, submit assignments, practice skills, share experiences, get feedback, etc. Figure 3 shows the website and application interfaces of ICE. It combines information and communication technologies and the traditional face-to-face classroom teaching. The aim of developing ICE is for learners not only to learn metaliteracy but also to become self-directed and selfreflective metaliterate students.

Online learning resources are often used in the education of university students. The online learning content includes module-specific core documents, class-specific documents, past exams, model answers, answer keys, educational videos, etc. Students can easily access these resources but nowadays are not limited to these online resources uploaded by instructors.

There are a large number of e-learning activities which can be integrated into classroom teaching. These activities bring convenience to knowledge collection, storage, and access and thus can boost students' engagement and align their expectations. There are three most used activities in the ICE:

(i) Lesson activity: it enables teachers to deliver teaching materials and/or practice activities in flexible ways. For example, a teacher can create a set of content pages or instructional activities that offer paths or options for learners. Alternatively, a set of multiple choice and matching questions can be created according to the instructional design.

(ii) Assessed assignment activity: it enables teachers to assign tasks, collect work, and provide grades and feedback. Students can submit word documents, presentations, spreadsheets, images, and audio and video clips individually or as a member of a group. Teachers are able to leave feedback comments and upload digital resources, such as marked-up student submissions or spoken audio feedback.

(iii) Self-study and self-assessment activities: they enable teachers to create and administer quizzes, e-learning games, and other online learning resources (e.g., video lectures, tutorials, online courses, e-books, and presentations). These activities are used to test learners' knowledge as well as challenge their skills. Besides, utilization of these activities can give learners better learning experiences.

The e-learning activities are developed for helping students to determine, access, understand, and evaluate information. On the other hand, online communications allow students to learn from others, giving opportunities to collaborate, incorporate, participate, use, produce, and share information. There are a variety of communication methods available in ICE. The chat function enables students to have real-time synchronous discussions. It is especially useful when students extend their discussions and review their coursework. For teachers, the chat function is also a good communication tool that they can use to respond to students' questions about assignments. Podcasting can be another function that enables learners to create a podcast and publish episodes. Students can subscribe to the podcasts through the web browser or ICE application. Comments are allowed to be added for episodes.

\section{Methods}

Academic literacies include critical thinking, database searching, and familiarity with academic conventions such as referencing, use of formal register, and the ability to manipulate a range of academic genres [17]. Nowadays, academic literacy has become a major concern since it is essential for students' success in higher education, particularly at universities in the UK where achievement is predominantly assessed through students' written work.

This paper hypothesizes that metaliteracy learning could be considered as a feasible approach to empower students in blended courses. The objectives are to investigate three pedagogical issues:

(i) Whether integrating practices of metaliteracy can support a blended learning experience and respond to academic literacy challenges

(ii) How the blended learning benefits metaliteracy development

(iii) What the challenges of integrating practices of metaliteracy with blended learning are

To adequately address the objectives, we used a questionnaire which contains both demographic questions and questions measuring the level of the student satisfaction with different e-learning resources, activities, and communications 


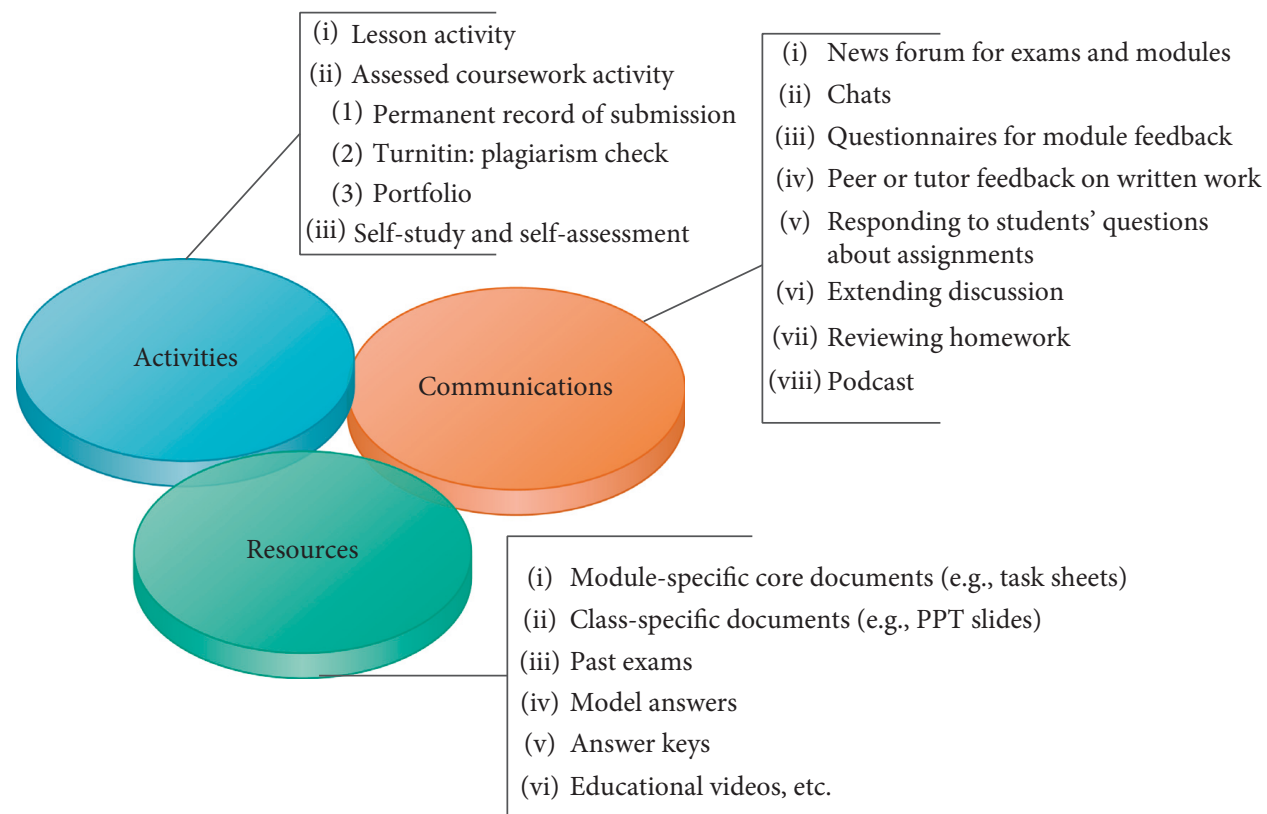

FIgURE 2: Interactive communication environment (ICE) used at Xi'an Jiaotong-Liverpool University (XJTLU).

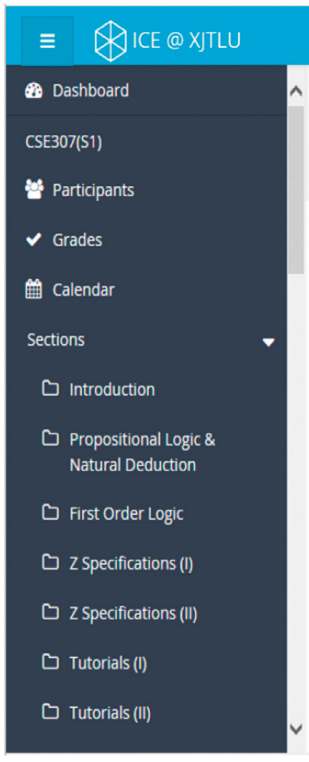

\section{$Q \bullet A D^{\text {Jieming Ma }}(9)$}

CSE307(S1) Formal Methods

Dashboard / My modules / CSE307(S1)

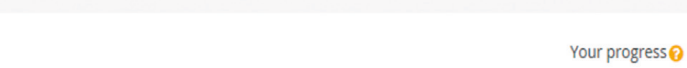

Module Title: Formal Methods

Module Code: CSE307

Originating Department Computer Science and Software Engineering

Module Level: 3 ( FHEQ level 6)

Module Credits (normally 5) : 5

Shared Programme(s) (please name all) BSc Information and Computing science

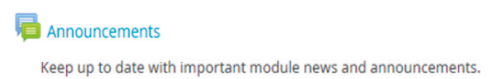

Keep up to date with important module news and announcements.

Module handbook and other important resources

The module handbook contains important information about module content delivery and assessment.

31. Office Hours Scheduler

(a)

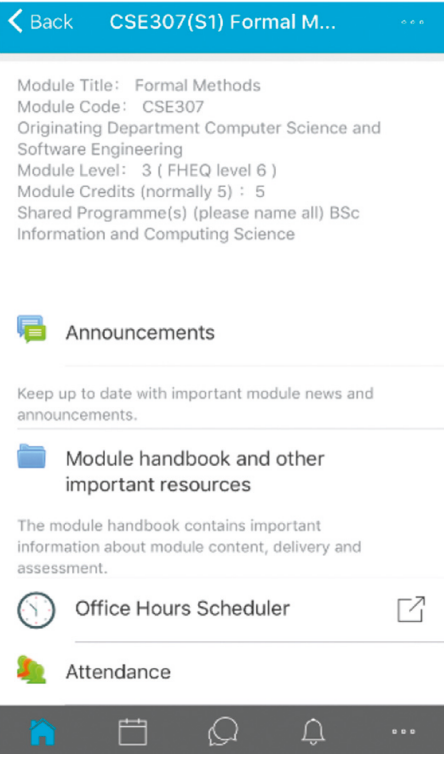

(b)

FIgURE 3: ICE interface: (a) website and (b) application.

in ICE. The questionnaire was used to investigate students' satisfaction and experience regarding their participation in the blended learning at XJTLU. The questions can be categorized into following items:

(i) Reflections on the use of online learning platform (OLP) and online assessment system (OAS) for enhancing blended learning experience

(ii) Benefits of integrating practices of metaliteracy with blended learning

(iii) Limitations of current practices in blended learning.
The questionnaire is written in both English and Chinese for ease of understanding. For each question used in the investigation, participants could reply with "strongly agree," "agree," "undecided," "disagree," or "strongly disagree." The data of this study are gathered by an online survey. As shown in Table 1, there are 236 students who have answered the voluntary survey $(34.3 \%$ male and $65.7 \%$ female participants). The study mainly targeted second-year and thirdyear undergraduate students registered at XJTLU since these students have much blended learning experience. The participants are grouped by their degree programs: 150 
TABle 1: Student sample data.

\begin{tabular}{lcc}
\hline Group & CST & ELL \\
\hline \multirow{2}{*}{ Program } & Computer Science \& & English Language \& \\
Participants & Technology & Literature \\
Male/female & 150 & 86 \\
& $72 / 78$ & $9 / 77$ \\
Year in university & Year 1: $64(42.7 \%)$ & Year 1: 1 $1.2 \%)$ \\
& Year 4: $15(10.0 \%)$ & Year 4: $13(15.1 \%)$ \\
\hline
\end{tabular}

All participates had previous blended learning experience.

Computer Science \& Technology (CST) students and 86 English Language \& Literature (ELL) students.

\section{Survey Results and Discussion}

In today's new digital learning environment, the learning outcomes can be affected by a good number of factors, such as the content of information and the format and delivery mode of the information itself [10]. Students can use computers and many portable digital devices for online learning. Our experiences with the implementation of blended learning illustrate that students' computer proficiency also affects the learning outcomes. Figure 4 shows the learners' reflections on using ICE. Over $65 \%$ of participates in CST indicated that they can operate both OLP and OAS skillfully. However, only $10 \%$ of participates in ELL agree that they are able to use the ICE well. It is not that hard to conceive of a situation in which students would give up using many useful online resources or activities mainly because of a certain degree of "ignorance": it is hard to use a software you do not know, or you have a lot of prejudices about. Programming languages, such as Java, PHP, Python, Ruby, C, C++, and C\#, are often used in online coding tests, which require fundamental programming skills. More CST students indicated that the OAS is more difficult to use.

This metaliteracy challenges us to consider creative teaching methods that use the modern information technologies. From Figure 5(a), we can see that more than $80 \%$ CST students perceived that the OLP, as well as the online learning materials, has helped them to acquire and develop understanding, knowledge, and skills. The OLP facilitates the expansion of possibilities in teaching and learning by supporting various forms of communication. More than $60 \%$ CST students perceived that the OLP can improve their communication with both teachers and fellow students. The number of ELL students who agree on the benefits of the OLP is lower than that of CST students. The reason behind this is that some ELL students prefer paper books rather than e-books and online learning materials. It can therefore be concluded that the OLP and OAS contributed to enhance student learning and promote their metaliteracy and metacognition in teaching and learning.

As evidenced by learners' reflections in Figure 6, integrating practices of metaliteracy with blended learning offers the following benefits:

(i) The interactive learning environment (ILE) encourages active learning and self-learning (69\% of the surveyed CST students and $47 \%$ of the surveyed ELL students). The ICE provides a platform for students where they can actively discuss and vocalize their understanding of concepts. Moreover, the blended approach forces students to look for information online dependently, rather than just relying on a lecturer or a text book.

(ii) The ILE enables more flexibility and the freedom to learn anytime, anywhere (80\% of the surveyed CST students and $62 \%$ of the surveyed ELL students). With online resources, activities, and communications, students can access materials without any constraints. Students can access the ICE on smartphones, tablets, and desktops which are tools they are already using daily. They also enable teachers to grade whenever they have a free time.

(iii) The ILE promotes student interest $(55 \%$ of the surveyed CST students and $44 \%$ of the surveyed ELL students). Many students today, who are familiar with online environments, prefer to have a variety of approaches to learn. The varied formats of teaching activities, such as video lectures, video conferencing, and educational games, also serve a purpose outside of entertainment and pleasureseeking activities.

(iv) The ILE drives personalized learning (83\% of the surveyed CST students and $77 \%$ of the surveyed ELL students). New information and communication technologies make it easier to individualize learning modules. Students studying in one classroom can move at different paces. With the ICE, teachers can visualize and track the learning progress of each student. This process can make it easier to identify which content needs extra attention or which contents students are more interested in.

(v) The ILE promotes metaliteracy development $(74 \%$ of the surveyed CST students and $69 \%$ of the surveyed ELL students). A study conducted by the Pew Research Center finds that $84 \%$ of American adults use the Internet [18]. By catering to students' preferred means of communication, chat function and online forums can connect lecturers with students more effectively. As students receive information outside of lectures mainly through ICE, their learning achievement and information literacy skills can be improved in a blended course.

From Figure 6, we can see that more than $60 \%$ students, both from CST and ELL, agreed that ILE combines traditional forms of learning with many forms of flexible learning, improving communications and making it easier for them to get personalized learning. Fewer students believe that ILE encourages active learning and can promote student interest. The reason behind this could be that online resources and activities cannot fully replace human dialogue and relationships in the learning process. Students could lose interest in learning if the blended course was not well designed. 


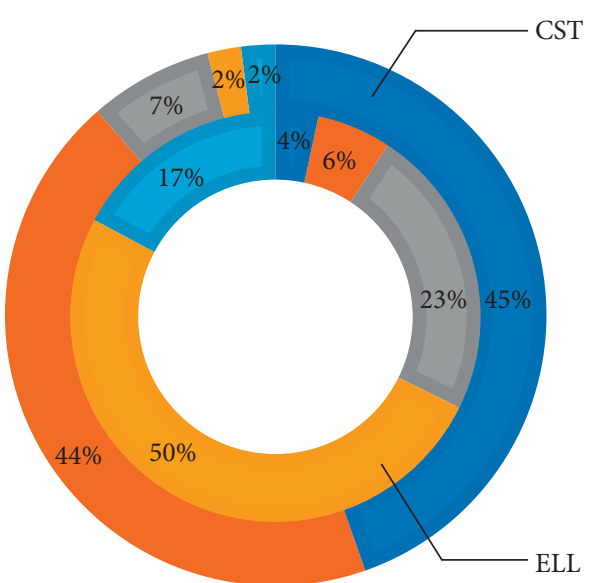

Strongly agree Agree

Undecided
Disagree Strongly disagree

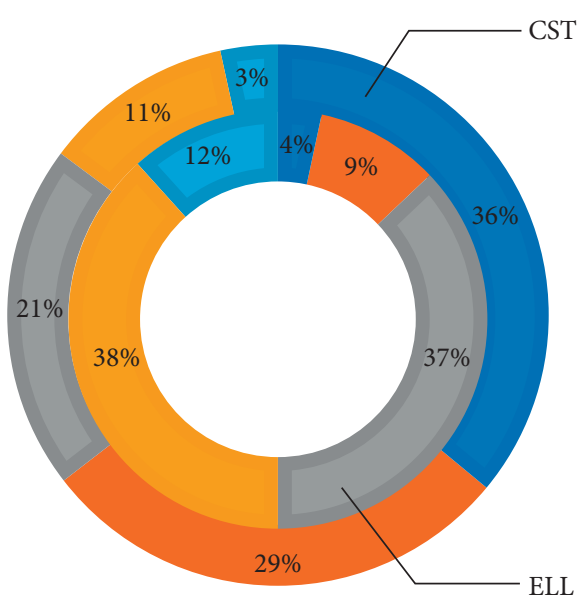

Strongly agree Agree Undecided

(a)

FIGURE 4: Learner reflections. Technical proficiency with ICE: (a) online learning platform (OLP) and (b) operate online assessment system (OAS).

(i) The OAS allows students to collaborate and share information with others.

(ii) The online quiz can enhance student learning.

(iii) The OAS enables students to acquire and develop understanding, knowledge, and skills.

(iv) The OLP allows students to collaborate and share information with others.

(v) The online resources can enhance student learning.

(vi) The OLP enables students to acquire and develop understanding, knowledge, and skills.

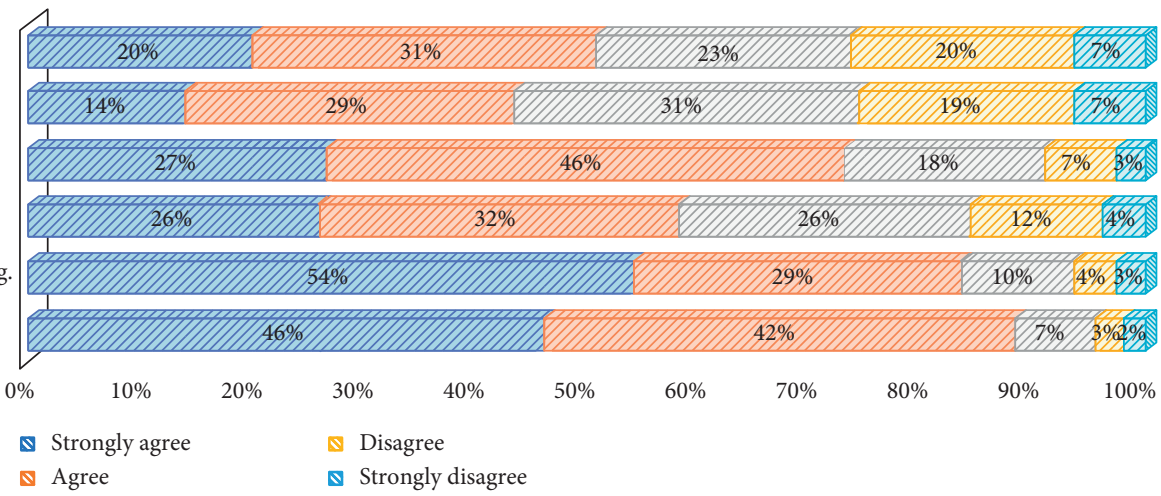

(a)

(i) The OAS allows students to collaborate and share information with others.

(ii) The online quiz can enhance student learning.

(iii) The OAS enables students to acquire and develop understanding, knowledge, and skills.

(iv) The OLP allows students to collaborate and share information with others.

(v) The online resources can enhance student learning.

(vi) The OLP enables students to acquire and develop understanding, knowledge, and skills.

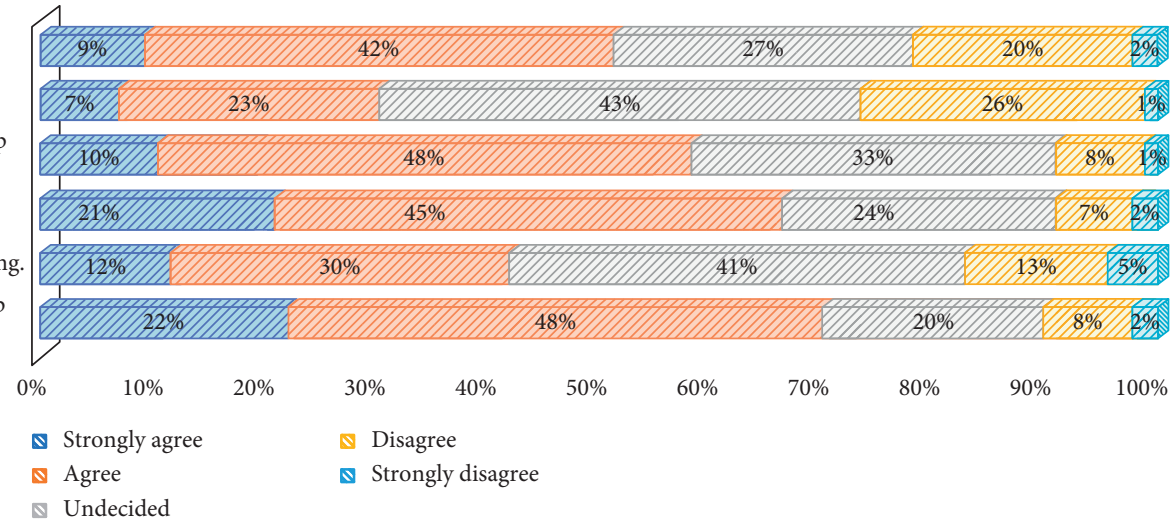

(b)

FIGURE 5: Reflections on the use of online learning platform (OLP) and online assessment system (OAS): (a) CST students' responses and (b) ELL students' responses.

Figure 7 further shows three problems that we encountered when integrating practices of metaliteracy with blended learning. (i) Students often experience information overload in blended learning courses ( $46 \%$ of the surveyed CST students and $57 \%$ of the surveyed ELL students). 

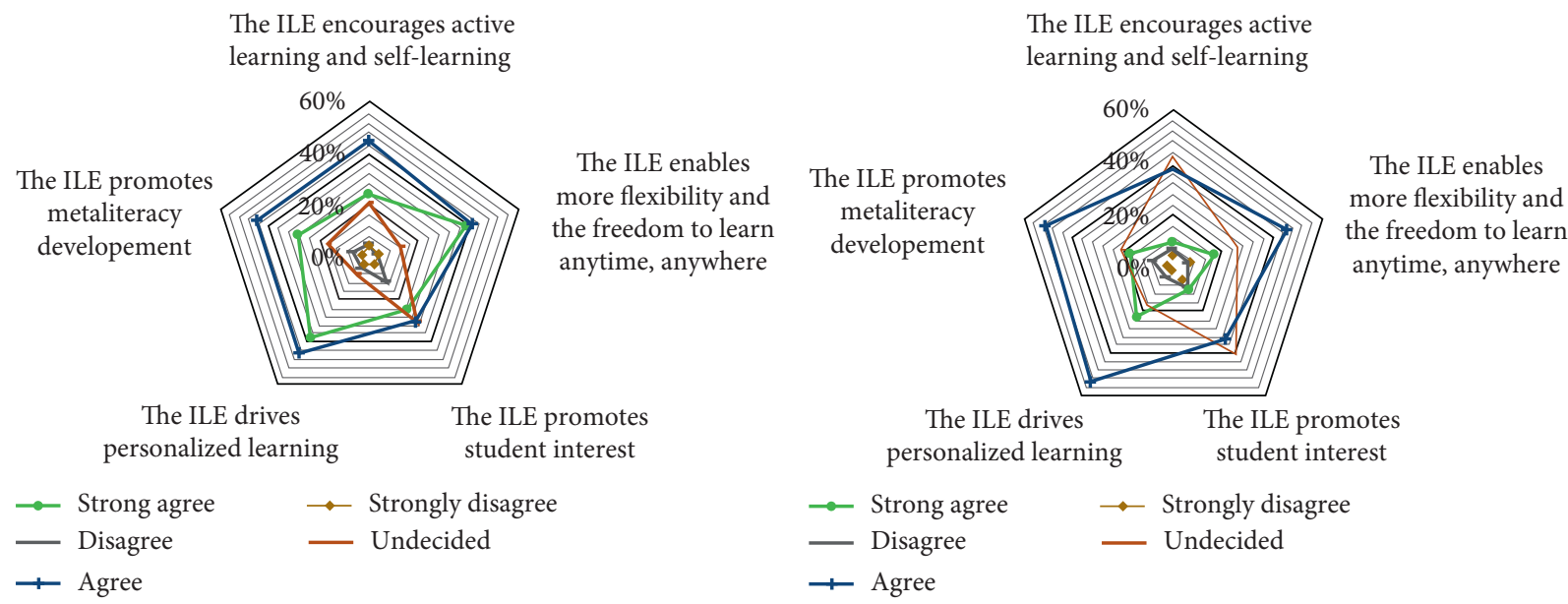

(a)

(b)

FIgURE 6: Learner reflections. Benefits of integrating practices of metaliteracy with blended learning: (a) CST students' responses and (b) ELL students' responses.

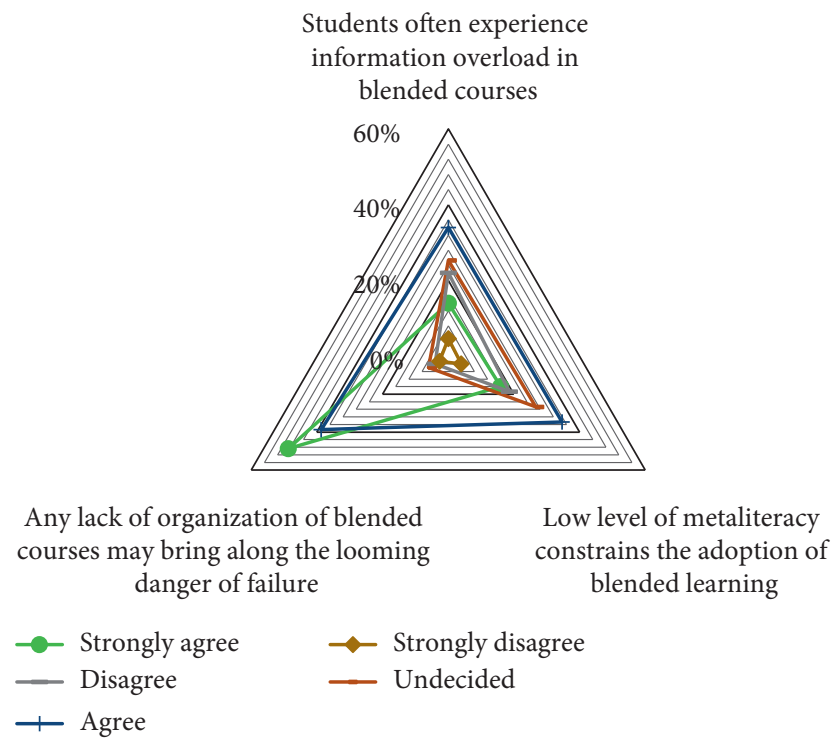

(a)

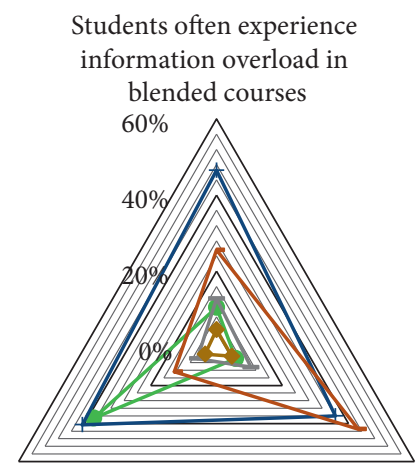

Any lack of organization of blended courses may bring along the looming danger of failure

Low level of metaliteracy constrains the adoption of blended learning

(b)

Figure 7: Challenges of integrating practices of metaliteracy with blended learning: (a) CST students' responses and (b) ELL students' responses.

As accessing information becomes easier and easier, many teachers prefer to share online supplementary materials and background information with students. However, it is also difficult for students to understand an issue and make decisions effectively when they receive too much information. Content overload is a significant barrier to using blended learning.

(ii) Low level of metaliteracy constrains the adoption of blended learning (51\% of the surveyed CST students and $42 \%$ of the surveyed ELL students). On the one hand, students' learning initiative may quickly decline if the technological resources used in the ICE are not reliable and not easy to use. On the other hand, the level of metaliteracy would be another barrier to using blended learning. Students will get annoyed easily due to the lack of knowledge of the technology. Solid technical support is therefore essential for both students and teachers. More than 37\% CST and ELL students strongly agreed that this is the main factor that affects their learning experience.

(iii) Any lack of organization of blended learning courses may bring along the looming danger of failure $(88 \%$ of the surveyed CST students and $78 \%$ of the surveyed ELL students). Too much information usually puts an unnecessary load on students. Any lack of organization of ICE, such as 
unreasonable schedule, unclear course map, and unsuitable supporting learning materials, will worsen the motivation and willingness of students.

\section{Conclusions}

The pace of application of information technologies in blended learning environments places emphasis on metaliteracy development. This paper reflects upon the experience of the delivery of blended courses at XJTLU and argues that the embedding of metaliteracy development is beneficial for enhancing the blended learning experience. A survey was conducted to estimate the feasibility of integrating practices of metaliteracy with blended learning. Although the computing proficiency of students from various backgrounds is different, survey results indicate an online interactive learning environment (ICE) has helped students improve their communications and acquire and develop understanding, knowledge, and skills. In addition, integrating practices of metaliteracy with blended courses motivates students to develop metaliteracy, promoting active, personalized, flexible learning experiences. On the other hand, the challenges of the integration work, such as information overload, low level of information literacy, and poor course organization, inform amendments of the learning environment.

\section{Data Availability}

The data used to support the findings of this study are available from the corresponding author upon request.

\section{Conflicts of Interest}

The authors declare that they have no conflicts of interest.

\section{Acknowledgments}

This work was supported by Xi'an Jiaotong-Liverpool University Teaching Development Fund (Grant nos. TDF 17/18-R16-111 and TDF 15/16-R11-091) and General Project of Jiangsu Institute of Higher Education-Assessment Committee (Grant no. 2018-Y08).

\section{References}

[1] B. Loch and R. Borland, "The transition from traditional faceto-face teaching to blended learning-implications and challenges from a mathematics discipline perspective," in Proceedings of the Ascilite, pp. 708-712, Dunedin, New Zealand, November 2014.

[2] B. Schwenger, "Enhancing students' tertiary blended learning experience through embedding digital information literacy," Journal of Perspectives in Applied Academic Practice, vol. 4, no. 1, pp. 71-77, 2016.

[3] K. S. Hanson and F. A. Clem, To blend or Not to Blend, Handbook of Blended Learning: Global Perspectives, Local Designs, Pfeiffer Publishing, San Francisco, CA, USA, 2006.

[4] E. Chew, N. Jones, and D. Turner, "Critical review of the blended learning models based on Maslow's and Vygotsky's educational theory," in Proceedings of the International
Conference on Hybrid Learning and Education, Springer, Berlin, Germany, 2018.

[5] E. E. Baro, "A survey of information literacy education in library schools in Africa," Library Review, vol. 60, no. 3, pp. 202-217, 2011.

[6] R. Alebaikan and S. Troudi, "Blended learning in Saudi universities: challenges and perspectives," Association for Learning Technology Journal (ALT-J), vol. 18, no. 1, pp. 49-59, 2010.

[7] D. Flywel and B. N. Jorosi, "Information literacy skills among the undergraduate students at the university of Livingstonia, Malawi," International Journal of Library and Information Services, vol. 7, no. 2, pp. 43-56, 2018.

[8] C. Armstrong, D. Boden, S. Town, M. Woolley, S. Webber, and A. Abell, "Defining information literacy for the UK," Library \& Information Update, vol. 4, no. 1-2, pp. 22-25, 2005.

[9] A. A. Ojedokun, Information Literacy for Tertiary Education Students in Africa, Third World Information Services Limited, Ibadan, Nigeria, 2007.

[10] T. P. Mackey and T. E. Jacobson, "Reframing information literacy as a metaliteracy," College \& Research Libraries, vol. 72, no. 1, pp. 62-78, 2011.

[11] E. Papleontiou-louca, "The concept and instruction of metacognition," Teacher Development, vol. 7, no. 1, pp. 9-30, 2003.

[12] C. Bruce, "Information literacy as a catalyst for educational change: a background paper," in Proceedings of the 3rd International Lifelong Learning Conference, Yeppoon, Queensland, Australia, June 2004.

[13] J. Elmborg, "Critical information literacy: implications for instructional practice," Journal of Academic Librarianship, vol. 32, no. 2, pp. 192-199, 2006.

[14] B. Ingraham, P. Levy, C. McKenna, and G. Roberts, "Academic literacy in the 21st century," in Contemporary Perspectives in E-learning Research: Themes, Methods and Impact on Practice, pp. 160-173, Routledge, New York, NY, USA, 2007.

[15] T. P. Mackey and T. E. Jacobson, Metaliteracy: Reinventing Information Literacy to Empower Learners, American Library Association, Chicago, IL, USA, 2014.

[16] Y. Wang, X. Han, and J. Yang, "Revisiting the blended learning literature: using a complex adaptive systems framework," Journal of Educational Technology \& Society, vol. 18, no. 2, pp. 380-393, 2015.

[17] R. McWilliams and Q. Allan, "Embedding academic literacy skills: towards a best practice model," Journal of University Teaching \& Learning Practice, vol. 11, no. 3, pp. 1-20, 2014.

[18] A. Perrin and M. Duggan, "Americans' internet access: 2000-2015,” Pew Research Center, vol. 26, no. 6, pp. 1-2, 2015. 


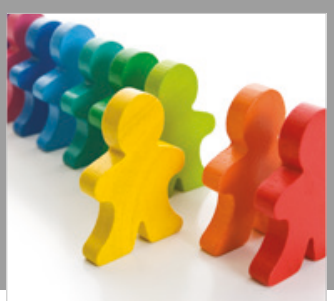

Autism

Research and Treatment
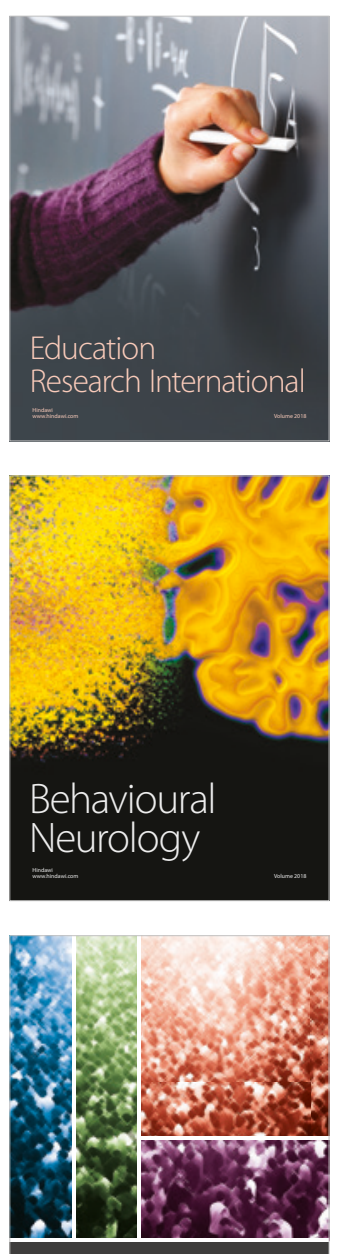

International Journal of

Population Research

$\underline{-m}$

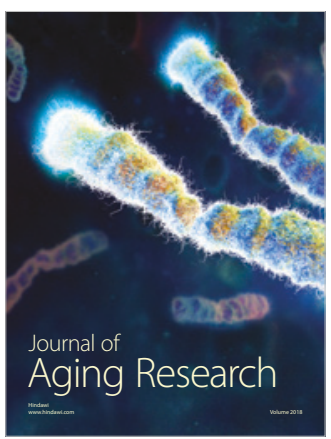

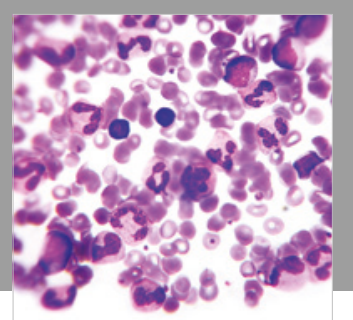

Pathology

Research International$$
=
$$

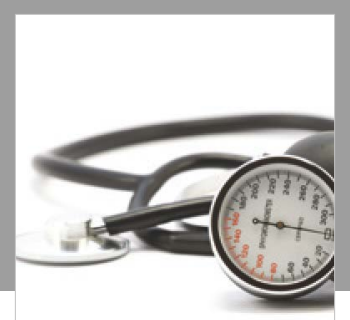

Nursing

Research and Practice

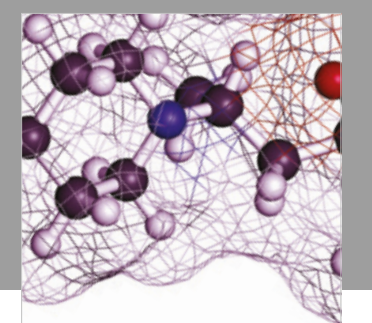

Pain

Research and Management

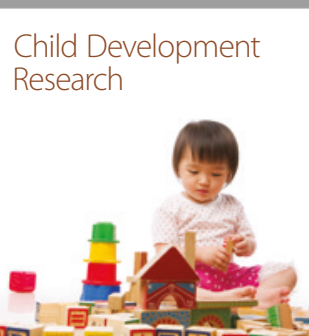

बाD

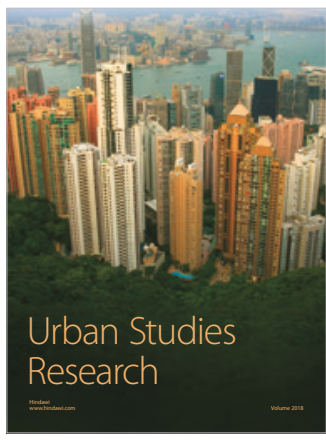

\section{Hindawi}

Submit your manuscripts at

www.hindawi.com
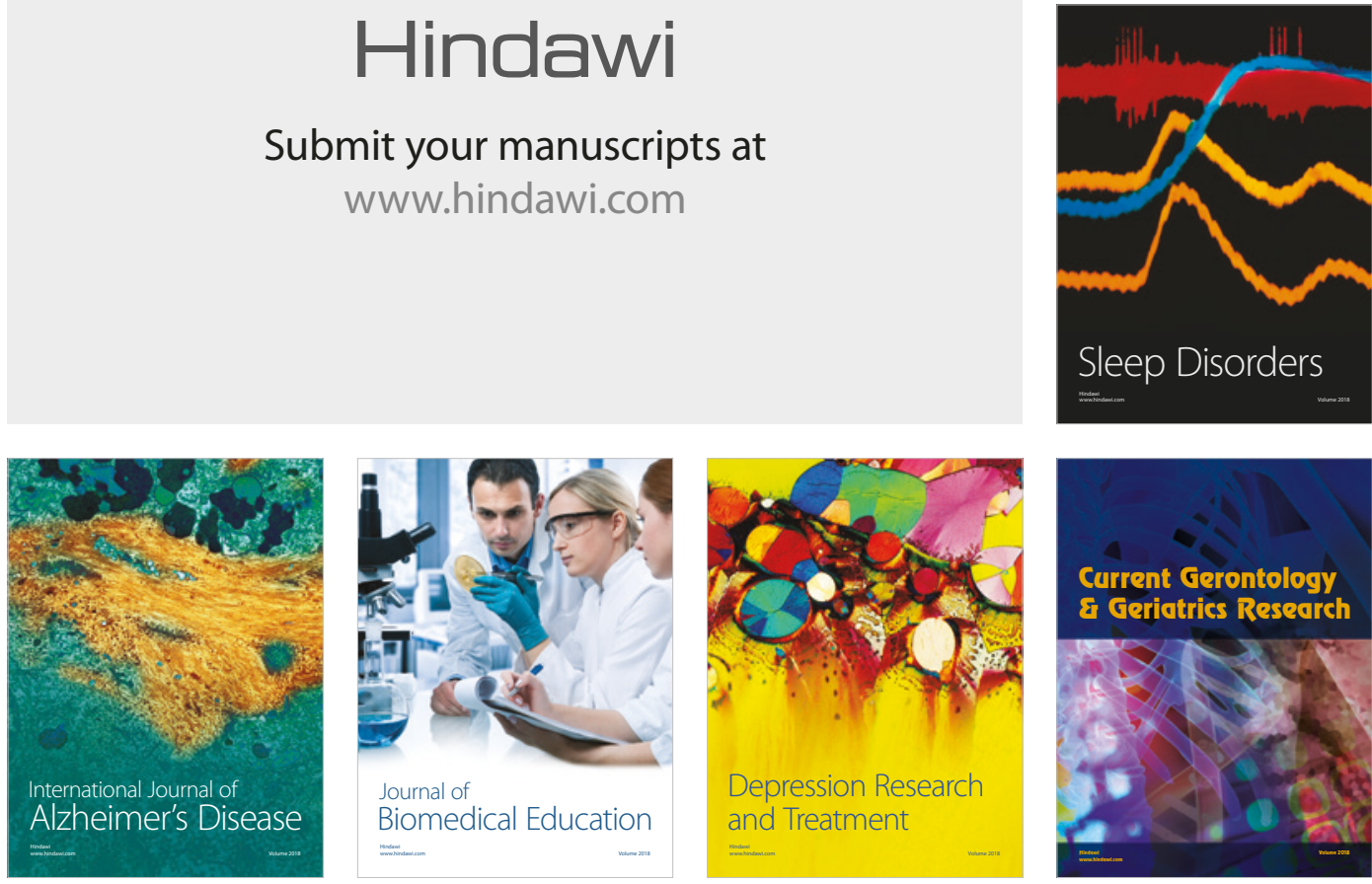

Journal of

Biomedical Education

$=$

smman

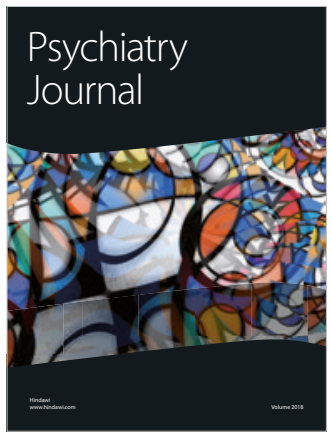

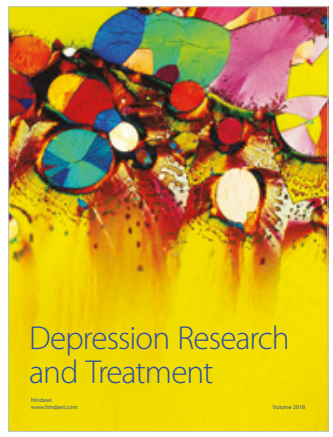
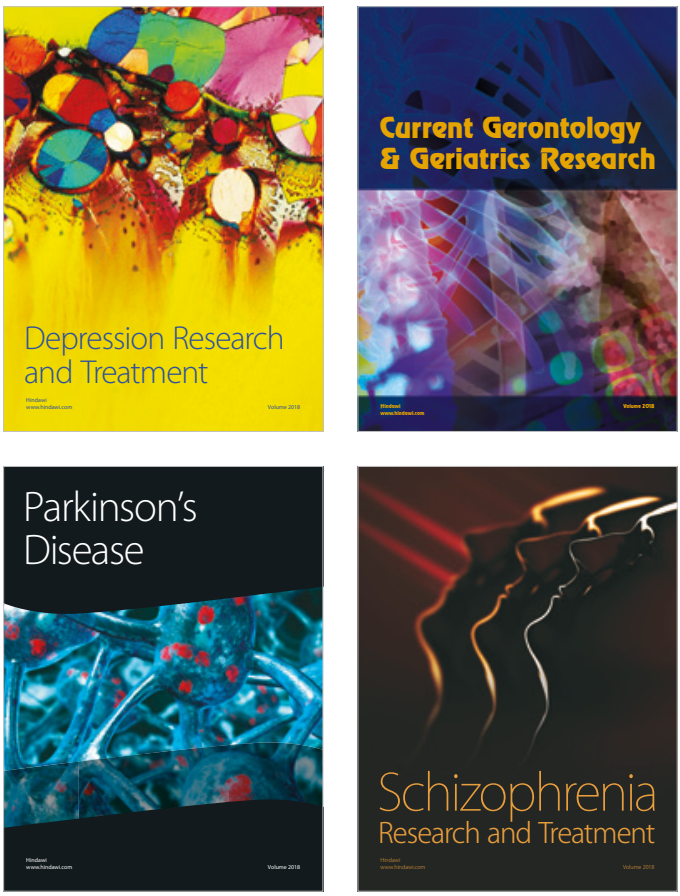